\title{
Hayvan Çalışmalarında Uygun Model Seçim Kuralları ve Etik Durum
}

\author{
Ethical Status and Rules for Selecting Models in Animal Studies
}

\section{Ayșe Altun ${ }^{1}$, İlknur Keskin ${ }^{2}$}

${ }^{1}$ İstanbul Üniversitesi, İstanbul Tip Fakültesi, Kadın Hast. ve Doğum ABD. Reprodüktif Endokrinoloji ve İnfertilite Bilim Dal, İstanbul

${ }^{2}$ Medipol Üniversitesi, Sağlık Bilimleri Enstitüsü, Histoloji-Embriyoloji ABD, İstanbul

\author{
Yazı̧ma Adresi / Correspondence: \\ Ayşe Altun \\ İstanbul Üniversitesi Tip Fakültesi, Turgut Özal Millet Cd, 34093 Topkapı-Fatih/İstanbul \\ T: +90551 $3896647 \quad$ E-mail: embaysealtun@gmail.com \\ Geliş Tarihi / Received : 24.01.2020 Kabul Tarihi / Accepted : 01.06.2020 \\ Orcid: \\ Ayşe Altun: https://orcid.org/0000-0002-2765-5766 \\ İlknur Keskin: https://orcid.org/0000-0002-7059-1884 \\ ( Sakarya Tip Dergisi / Sakarya Med J 2020, 10(2):359-364) DOI: 10.31832/smj.679500
}

Öz

Bilginin öğrenilmesi araştırmalar yapılarak elde edilebilmektedir. İnsan anatomisi, fizyolojisi, doku-organ sistemi üzerinde bilgi elde etmek herhangi bir canlyya zarar vermeden olmalıdır. İnsanlarla ilgili yapılan çalıșmalar için insan biyolojisini taklit edebilmek için laboratuvar hayvan modelleri kullanılmaktadır. Deneysel hayvan çalışması için insandaki klinik karşılığına uyarlanabilen deney hayvanı ve deney dizaynı gerekmektedir. Bu bağlamda çalışmanın insana sağlık sektöründe tedavi edici veya farmakolojik etkiyi arttırılacağına inanılan çalışmalarda kullanılmalıdır. Deney dizaynı planlanması daha çok en başta hücre, doku, hücre kültürü seviyesinde planlanabilmelidir, bunun sağlanamaması deney sonucunda veri azlığı düşünüldüğü durumda deney hayvanı kullanılmalıdır. Bilimin ilerlemesi için yapılan bu çalışmalarda yapılan zararın ve yararın oranı göz önüne alınarak hayvan etiğine en uygun şekilde yapılabilirliği sağlanmalıdır. Araştırmalar için hayvan hakları ve etiği esas alınıp bilimsel yararlılık sağlanmalıdır.

Anahtar Deney hayvanı, etik durum, hayvan modelleri, laboratuvar hayvanı ilkeleri

Obtaining the knowledge is achieved by studies. However while achieving this goal, gathering information about human anatomy, physiology, and tissue organ system should be fulfilled without harming any living being. Experimental in vivo studies require experimental animal and experiment design which can substitute the human biology as reciprocal to human in clinic. In this regard, subjected studies should be used in the researches that are envisioned to increase the therapeutic or pharmacological effects in human health. Experimental design should be planned primarily at the cell, tissue and cell culture level. Nonetheless, if obtained data from this in vitro study is not enough to interpret or conclude the research goal, animal subjects should be used. In these studies which are performed to advance the science, feasibility of animal ethics should be ensured by considering the animal harming ratio and this ratio should be lowest within the scope of research. Scientific utility should be provided as based on animal rights and ethics for the researches.

Keywords Animal experiments, ethics status, animal models, laboratory animal principles 


\section{GIIRIŞ}

İnsan biyolojisi ya da hal-hareket durumlarını bilimsel açıdan araştırmak için laboratuvar hayvan modelleri kullanılması öngörülmektedir. Hayvan modeli seçiminde taklit edilecek canlıya anatomik, fizyolojik açıdan en uygun olan adapte olabilen tür seçilmelidir. Bu seçim var olan bilimsel çalışmada nihai sonuca götürme ve faydalı bilgi elde etme seçeneğini vermelidir. $\mathrm{Bu}$ nedenle literatür araştırması planlanan deney için mümkün olduğunca yoğun ve son güncel veriler göz önünde bulundurmalıdır. Yeni bir model dizaynı için olabilecek olumlu olumsuz tüm sonuçlar çıkarılarak deney sonucunu anlamlı kılabilme potansiyeli araştırılmalıdır. Her deney hayvanı dizaynı o gerçek durumu yansıtamamasından dolayı deney çıkarımı birçok bilimsel yayınla desteklenmelidir.

Deney hayvanları üzerine çalışma planlanması durumunda hayvanın yaşam kalitesi, bakım, beslenme imkanları en iyi standartlarda tutulmalı hayvan haklarına zarar verebilecek durumlar ekarde edilmelidir. Hayvanların barınd1rılacağı odaların ısı ve nemi kullanılacak hayvanın türüne uygun olmalı, hayvan bakıcıları hayvan bakımı ile ilgili eğitim almış ve etik kuralları bilen kişiler olmalıdır. Deneye dahil edilecek hayvanların düzenli sağlık kontrollerinin yapılmış olması gerekmektedir. Herhangi bir deney için kullanılan hayvan ikinci kez kullanılmamalıdır ve deney bitiminde uygun ötenazi şekliyle kurallara uygun olarak hayvan ölümü yapılmalıdır. ${ }^{1}$ Araştırmada kullanılacak hayvanlar, bakanlık tarafından ruhsatlandırılmış olan üretim merkezlerinden alınmalı ve yönetmeliklerde anlatılan biçimde taşınma işlevleri yerine getirilmelidir.

Bilimsel olarak yapılacak olan deney hayvanı çalışmalarında hayvan hakları ve koruması esas alınmalıdır. Söz konusu hayvan çalışmaları hayvan yararına yasal düzenlemeler, iyileştirmeler yapılmıştır.,3 Deneyde kullanılacak hayvan hakları ve etiği konusunda Avrupa ve Amerika'da çıkarılan yasalar sayesinde de bu hayvan yararı tutumlar sağlanmış$\operatorname{tir}^{4,5}$

\section{Deneysel Hayvan Modeli Seçim Kriterleri}

Bilimsel araştırmalar için deney hayvan modeli seçilirken seçilicek hayvanın insan modeline genetik, fizyolojik, anatomik yönden uygunluğu özellikle dikkat edilmesi gereken kriterlerdir. Elde edilmesi beklenen sonuçlar için çalışmaya dahil edilen hayvan sayısı, yaşı, cinsi, ırkı, boy-kilosu optimize edilmeli ve bu parametreler göz önüne alınarak seçim yapılmalıdır. Hayvan modelinin uygunluğu bilimsel araştırmanın sonuç doğruluğunu direk etkilemektedir. $\mathrm{Bu}$ nedenle deney verilerini hayvan modelinin kendisi, deneysel faktörler ve deney dışı faktörleri etkilemektedir. ${ }^{6,7,8}$

$\mathrm{Bu}$ faktörler göz önüne alınarak deney düzenlemesinde uygun hayvan modeli tercih edilmelidir ve deneyde oluşabilecek olumlu ve olumsuz etkileri belirlenmelidir. Deneyi etkileyecek hayvan faktörleri; hayvanın vücut hacmi, yaşam süresi, yaşı, cinsiyeti, gebelik durumu, biyolojik ritmi, üretim tarzı, genetik ve mikrobiyolojik durumlardır., Deney dışı faktörler arasında barınma ortamı, beslenme ve bakım koşulları önde gelmektedir. ${ }^{10}$ Deney ortamında kullanılacak hayvan modelinin çevresel koşullarının değişmesi hayvan üzerinde stres faktörü oluşturarak deney verilerini negatif şekilde olumsuz etkileyecektir. Dolayısıyla deney dizaynı esnasında hayvan biyolojisini, yaşam kalitesini ve davranışını etkileyebilecek çevresel faktörler elimine edilmelidir. ${ }^{11}$

Deney hayvanı çalışmaları, karmaşık süreçlerin daha basit sistem üzerinde denenmesi ve model oluşturulması olarak tanımlanır. Çalışma amaçları genellikle insan üzerine denenmeden önce hayvan üzerinde kanitlamaktır ve çalışma konusuyla ilgili yeterli bilgi birikimi sağlamaktır. Deneylerde kullanılan hayvan türleri genel olarak fare, rat (sıçan), kobay, tavşan, kedi, köpek, koyun, domuzdur. Çalışmalarda daha çok fare, rat, kobay en çok tercih edilen omurgalı türleridir. Çoğunlukla kanser, antikor, ilaç , aşı çalışma alanları için kullanılır. ${ }^{1,12}$ Ayrıca, hayvan boyutunun küçük olması çalışma alanı için idealdir aynı zamanda manipulasyonunun kolay olmasi, kolay elde edilebilmesi, yaşam sürelerinin kısa oluşu nedeniyle de çalışmalar bu 
türler üzerine yoğunlaşılmıştır.

Deney hayvanı araştırmalarında kullanılan dört farklı model vardır. Bunlar indüklenmiş, spontan, negatif, olası modellerdir. İndüklenmiş modellerde amaç, insanda görülen hastalık, sorunun hayvanda da oluşturulmasıdır. Bunlar da ilaçlar, cerrahi işlemlerde veya genomik transferle genetiği değiştirerek sağlanabilir. Hayvanda insan doğasında var olan hastalığı yaratarak olan sorunu tedavi etmeye yönelik çalışma yapılabilir ve çalışma sonunda tedaviye düzgün yanıt veren yöntem insana uyarlanabilirliği için destek çalışmaları beraberinde getirir. Bu tarz çalışmalar içinde tür seçimi yapmak gereklidir.

Bazı hayvan türleri genetik olarak kendiliğinden hastalık üretmektedir ve oluşan bu hastalık şekli insanlarda da benzer bir hastalığı yansıyacak bulgular içeriyorsa bu hayvanlar spontan model olarak seçilir ve çalışmalar bu tür kuram üzerine kurulur. Çalışma planlanırken hayvan türü, soyu bilinmesi gereklidir çünkü en önemli nedeni kullanılan hayvanın negatif model olabilmesidir. Negatif model olan hayvanlarda bazı hastalık türleri, semptomları gelişmez ve çalışmada verilen kimyasal, uyarı, indüksiyon ajana karşı hayvan her hangi bir cevap veremez. Bu yüzden çalışma planı yapılırken dikkat edilmesi gereken bir husustur. Hayvanlarda tanımlanmış bir hastalığın insanda görülebilirliği amacıyla yapılan çalışma planında olası modeller kullanılır. Bu durum insanda benzer bir hastalık görüldüğü zaman hayvan türlerine uyarlanarak üzerinde bilimsel çalışmalar yapmayı mümkün kılar. ${ }^{13}$

Çalışma dizayn ederken çalışılacak hayvanı belirlemek için ayrıntılı literatür taraması, araştırması yapılarak uygun soy belirlenmelidir. Deney için seçilen hayvan türü, çalışmanın amacına ve sonucuna ulaşabilecek tüm özellikleri barındırmalıdır. ${ }^{14}$ Planlanan çalışma için öncesinde kontrol çalışma yapmak gereklidir. İstenen sonucu verip vermemesi konusunda fikir sahibi olunmalıdır. Kontrol çalışma istenen sonucu vermiyor ise seçilen hayvan türü, çalışma basamakları tekrar incelenerek ön çalışma ile fazlaca hay- van kullanımı önlenmiş olunacaktır. Ayrıca çalışmayı yapacak olan araştırmacıların deney hayvanları konusunda bilgi, yeterli el becerisi ve deney hayvanı kullanım sertifikası bulunmalıdır. Hayvana müdahale esnasında doğabilecek sorunlara karşı tecrübe, öngörüsü olabilecek kişiler ile çalışma planlanmalıdır. ${ }^{15}$

\section{Deney Hayvanı Çalışmalarında Etik Durum}

Tibbi bilimler, temel bilimler, farmakoloji ve hayat bilimleri gibi birçok alanda deney hayvanı bilimsel araştırmalar için kullanılmaktadır. İnsan vücudunun genel fizyolojisi, biyokimyası ve hormonal yapısı gibi insana dair birçok konu hakkında bilgiye erişebilmek deneysel hayvan modelleriyle çalışılarak elde edilmektedir. Bu tür deney hayvanı çalışmalarının bilimsel ve etik kurallara uyularak yapılması esastır. Çalışmayı yapacak olan araştırmacının, hayvanı yetiştiren veteriner hekiminde hayvan koruma, besleme, bakımı ile ilgili eğitilmeli ayrıca hayvan haklarını koruması konusunda bilgilendirilmelidir. ${ }^{16}$

Hayvan deneylerinde çalışmayı planlayan araştırmacıların dışında projenin bilimsel ve etik yönden değerlendirilmesi gerekmektedir. Çalışma projelendirilirken proje kapsamı tamamıla hayvan hakları ve korumaya yönelik şekilde olmalıdır ve proje etik kurula sunulmalıdır. Deney hayvanı çalışmaları Avrupa birliğindeki etik kurullar (Ethics committees for animal experimentation), Amerika birleşik devletleri değerlendirme komisyonları (Institutional animal care and use committees) düzeyinde bağımsız olarak değerlendirmelidir. Ülkemizde hayvan deneyleri etik kurulları ile ilgili yönetmelikler çıkarılmıştır ve çalışma dizaynı tamamıyla bu kurallara göre yazılmalıdır. Bu kuralların en önemli üç başlı̆̆ mevcuttur, etik uzmanları ve kurul üyeleri 3R kuralını bilmek zorundadır ve bu kuralla ilgili yeterince deneyime sahip olmalıdır. ${ }^{17}$

\section{R kuralı}

Hayvan deneylerinin büyük çoğunluğu tıp alanlarında olmaktadır ve genelde temel amaç insanda var olan hastal1ğa karşı tedavi dizayn etmektir. Bunun amacı ise, hayvan 
üzerinden bulanan tedavi ile insanın daha az acı duyması daha verimli bir tedavi sonucu almasıdır. Amaç insani yönden insan korumasıyken bir yandan hayvan hakkı ve koruması göz ardı edilmektedir. Bu sebepten dolayı araştırmacılar arasında etik açıdan tartışmaları beraberinde getirmektedir. Bilimsel bu yanlılık ve tartışma ortamının doğması esasında hayvan hakları ve etiği ile ilgili durumun doğmasına ve bununla ilgili girişimlerin doğmasına sebep olmuştur. Bilimsel hayvan çalışmalarında hayvana gereğinden fazla acı, fazlaca hayvan kaybı olmamalıdır. Bu anlamda hayvan çalışmasında hayvan açısından az kayıp, az acı ve bilime faydalı sonuç getirecekse tercih edilebilinir. Bununla ilgili olarak, ilk defa William Russell ve Rex L. Burch tarafindan "The principles of humane experimental technique" adlı eserler yazıldı ve bu eserde hayvan haklarını korumayla ilgili kuralları içermektedir. 3R kuralı (orijinal adlariyla Reduction, Refinement ve Replacement) tanımlanarak araştırmacılar tarafından benimsenmesi ve uygulanması gerekmektedir.18 Son yıllarda bu üçlüye eklenen bir başlık olan Responsibility ile birlikte tamamlanmaktadır. Burada savunulan görüş gerek hayvan refahı ve gerekse bilim adamlarınca kabul görmüş ve günümüz biyoetik kurallarının temelini oluşturmuştur.

\section{Reduction}

Bu kelimenin Türkçe karşılığı azaltmadır. Russel ve Burch'ün eserindeki orijinal tanımıyla bu ilke planlanan proje için gerekli, yeterli bilgiye ulaşabilmek için hayvan sayısını minimal tutmak ve hayvanların sayısını azaltmak şeklinde ifade edilmektedir. ${ }^{19}$ Yapılan çalışmaları tekrar etmemek, bilinçli şekilde deney yapmak ve seçilen hayvanın doğru seçilmesi gerekmektedir. Bunların sağlanamaması durumunda gereğinden fazla hayvan kullanılacaktır ve deney sonucunda istenilen faydalı bilgiye ulaşılamayacaktır. Bir başka deyişle, en az sayıda hayvan kullanarak en iyi sonuca varmaktır. Bunun için düşünülen çalışma için iyi bir literatür araştırması yapılarak daha önce benzer çalışmanın olup olmadığını tespit etmek gerekmektedir. ${ }^{15}$ Benzer çalışma olmaması durumunda çalışmaya yeterli bilgi ve sonucu verebilecek optimum hayvan sayısı belirlenmeli- dir ki bunun içinde seçilecek hayvan türü, soyu yaş gibi parametreler göz önünde bulundurularak sayı belirlenmelidir. $^{18}$

\section{Refinement}

İkinci olan bu kural hayvanın refahı, konforunu öngörmektedir ve bunu ön plana koymaktadır. Deney hayvanları deneye seçildiği zamandan ölüm süresine kadar rahat yaşam koşulları içerisinde olması gerekmektedir. ${ }^{19}$ Deneyin çalışma modelinde oluşturulan o model için en az acı ve en az eziyete maruz birakılacak yöntem tercih edilmelidir. Araştırmanın sonucunu verebilecek en uygun modelin ağrı ve acının minimal olduğu düzeyde planlanmalıdır ve bu kural göz önünde bulundurularak çalışma projelendirilip etik kurula sunulmalıdır. Bu kurala göre yöntemin olumsuz yönlerini azaltma ve verimliliğini arttırma sağlanmalıdır. Uygulanacak tüm işlemler boyunca yaşama sayg 1 ilkesiyle hareket edilmelidir. ${ }^{20}$

\section{Replacement}

Bu kavramda amaç, aynı güvenilirlikte sonuçlar verebilecek başka model ya da materyaller üzerinde çalışmanın yapılmasıdır. Eğer çalışmanın karşılığında aynı veri sonuç elde edilecekse doku ve organ kültürleri, bilgisayar modelleri, hücre ve hücre kültürlerin kullanılması ön görülür. ${ }^{15}$ Deney hayvanları kullanım sertifikaları gibi eğitimsel çalışmalar da yapay deney hayvanları, filmler, görseller tercih edilmelidir. Ancak bu alternatif yöntemler her zaman deney hayvanlarından elde edilecek verilerin yerini tutamadığından klasik deney hayvanı tabanlı deneyler araştırmaların önemli bir kısmını oluşturmaktadır. Bunun asıl nedeni, insan ve hayvanların fizyolojik ve patolojik durumlardaki işlevlerinin bütünsellik göstermesi ve çeşitli organ ve sistemlerin etkileşim halinde bulunmasıdır. ${ }^{15}$

\section{Responsibility}

Bu ilke temelde laboratuvar hayvanını bir değer olarak görüp bunlara karşı sorumluluklarını bilmesini ve ona göre davranmasını, yeni yöntemlerin ve teknolojilerin geliştirilmesi ile kişisel sorumluluğunun arttırılmasını öngörmek- 
tedir. ${ }^{21} \mathrm{Bu}$ nedenle hayvan deneylerinin yapılabilmesi için birtakım kurallara uyulması gerekmektedir. Bu kuralların belirlendiği kanunlar, yönetmelikler, yönergeler ve kılavuzların temel amacı deney hayvanlarının haklarını korumak, araştırıcının deneylerini ve bunlardan elde edeceği verilerin güvenilirliğini sağlamak ve sonuçta yüksek standartlarla yapılan çalışmalarla bilime özgün bilgilerin katılmasının önünü açmaktır. Buna bağlı olarak, araştırmacıların konuyla ilgili mevzuata hakim olması gerekmektedir.

$\mathrm{Bu}$ kurallar doğrultusunda planlanmış olan çalışma sonunda hayvana etik davranılmasının en fazla ihtiyaç duyulduğu kısım deney bitimidir. Deney bitiminde hayvanının öldürülmesinin gerektiği durumlarda, deney hayvanlarının acı çekmeden öldürülmesi için kabul edilmiş kurallar uygulanmalıdır. Deney hayvanı herhangi bir nedenle, çalışmanın prosedürü dışında, şiddetli, beklenmeyen bir ağrı, huzursuzluk dolayı acı çekerse, araştırmacı tarafından hemen ötenazi (güzel ölüm) uygulanmalıdır. Ötenazi içinde etik kurallara uygun olarak kimyasal veya fiziksel ötenazi seçeneği araştırmacının tecrübe ve deneyimine en uygun olanı seçilmelidir. Ötenazi uygularken amaç, hayvanın bilincini hızla yitirmesini sağlamaktır ve en uygun metod uygulanmalıdır. Fiziksel olarak ötenazi yöntemleri servikal dislokasyon, dekapitasyon, sıvı azot içinde dondurma, mikrodalga, elektrik akımı gibi birçok yöntem mevcutken kimyasal ötenazi yöntemlerinde enjeksiyonla yüksek dozda anestezik maddenin verilmesi tercih edilir. Deney sonunda hayvanda acının artması ya da deney anında beklenmedik şekilde oluşan bu durumda araştırmacının etik şartlar altında acı ve eziyeti durdurmalıdır.

\section{SONUÇ}

Deney hayvanları çalışmaları çok farklı alanlarda tercih edilmektedir ve elde edilen bilimsel bilgilerin büyük çoğunluğunu oluşturmaktadır. Bilimsel deney hayvanı projeleri için önemli husus uygun hayvan modeli seçimidir ve bilimsel sonucu verebilecek en az sayıda hayvan kullanılmalıdır. Deneysel bir hayvan modeli oluştururken, modelin insan biyolojisine, fizyolojisine, biyokimyasına en uygun cevabı, sonuç ve veriyi verebilecek hayvan türü seçilmelidir. Bilimsel çalışmaların artması ve bilimin ilerlemesi deney hayvanları üzerinde çalışmalar yapmayı gerektirmektedir ve çalışmaların insanlığa ne derece fayda sağlayabilecegi öngörülmelidir. Hayvansal çalışmanın planlanmasında esas amaç insanlığa yarar ile birlikte etik kurallar içerisinde hayvan haklarını koruyabilmektir. Her ne kadar hayvan haklarını korumaya yönelik etik kurallar olmasına rağmen insanlık için belli oranda hayvan eziyete maruz kalmaktadır. Bu maruziyeti en aza indirecek çalışmalar ile araştırmacılar deneysel çalışmalarında hayvan haklarını ve etiğini esas alarak insanlığa yararlı bilgiler sağlamayı hedeflemelidir. 
Sakarya Tip Dergisi 2020;10(2):359-364

ALTUN ve Ark., Hayvan Çalışmalarında Uygun Model Seçim Kuralları ve Etik Durum

\section{Kaynaklar}

1. Utkan ZN, Cantürk NZ. Deney Hayvanlarının ve Deney Modellerinin Seçimi. İç: Cantürk NZ ve Sayek İ, ed. Cerrahi Araştırma. İstanbul: Nobel Matbaactlik; 2005:125-9.

2. Hayvan Haklart Evrensel Bildirgesi. Unesco. Paris.1978.

3. Deneysel ve Diğer Bilimsel Amaçlarla Kullanılacak Omurgalı Hayvanların Korunmast Hakkindaki Avrupa Konvansiyonu (European Convention for the Protection of Vertebrate Animals Used for Experimental and Other Scientific Purpose Avrupa Konseyi (ETS 123) 1986.

4. Deneysel ve Diğer Bilimsel Amaçlarla Kullanılan Hayvanların Korunması Hakkında Avrupa Direktifi (Avrupa Birliği 86/609/EEC), 2010.

5. Yaban Hayvanlarının Kullanıldı̆̆ı Çalışmalarda Nesli Tükenmekte Olan Yabani Hayvan ve Bitkilerin Uluslararası Ticaretine İlișkin Sözleșme (CITES) 1979.

6. De Aguilar-Nascimento JE. Fundamental steps in experimental design for animal studies. Acta Cirargica Brasileira 2005; 20(1): 1-8.

7. Lipman NS, Perkins SE. Factors that may influence animal research. In: Fox JG, Anderson LC, Loew FM, Quimby FW (ed). Laboratory Animal Medicine. Academic Press. Amsterdam, Netherlands, 2nd edition., 2002;1143-1165.

8. Wood MW, Hart LA. Selecting appropriate animal models and strains: Making the best use of research, information and outreach. AATEX 2008; 303-306.

9. Morrow PE, Haseman JK, Hobbs CH, Driscoll KE, Vanessa VU, Oberdorster G. The maximum tolerated dose for inhalation bioassays: Toxicity vs overload. Fundamental and Applied Toxicology 1996; 29: 155-167.

10. Wolfensohn S, Lloyd M. Handbook of Laboratory Animal Management and Welfare, Blackwell Publishing Ltd. Oxford, UK, 3rd ed., 2003.

11. Maxwell SE, Delaney HD.Guide for the care and use of laboratory animals: Eighth edition 2001.
12. Designing experiments and analyzing data. Belmont, California:Wadsworth Publishing Company, 1989.

13. Naycı S. Hayvan Çalışmalarında Planlama ve Uygun Model ve Denek Seçimi Nasıl Yapılmall? Planning Experimental Studies and Selection of an Available Animal Model? Turk Toraks Derg 2013; 10-4.

14. Pauwels RA, Germonpre PR, Kips JC, Joos GF. Genetic control of indirect airway responsiveness in the rat. Clin Exp Allergy 1995;25:55-60.

15. Oral M, Çakar S. Deneysel Hayvan Çalışmalarında Etik Prensipler. Anestezi Dergisi 2005; 13 (2): $75-82$.

16. Olsson AS, Robinson P, Pritchett K, et al. Animal Research Ethics. In: Hau J, Van Hoosier Jr GL, Handbook of Laboratory Animal Science. Volume I Essential Principles and Practices 2nd ed. USA CRC PRESS; 2003; 13-31.

17. Hayvan Deneyleri Etik Kurullarının Calıșma Usul ve Esaslarına Dair Yönetmelik. T.C. Çevre ve Orman Bakanlı̆̆. Resmi Gazete 06.07.2006, Sayı: 26220.

18. Ghasemi M, Dehpour AR. Ethical considerations in animal studies. J Med Ethics Hist Med 2009; 2: 12-15.

19. Kolar R. Animal experimentation. Sci Eng Ethics 2006; 12: 111-122.

20. Pereira S, Tettamanti, M. Ahimsa And Alternatives - The Concept Of The 4th R. The CPCSEA in India. Altex.2015; 22(1), 3-6.

21. Franco N.H, \& Olsson, I.A.S.Scientists and the 3Rs: Attitudes to Animal Use in Biomedical Research and the Effect of Mandatory Training in Laboratory Animal Science. Laboratory Animals.2014; 48(1), 50- 60 